\title{
THE LIABUITY OF A TRANSFEROR BY DELIVERY . AND OF A QUALIFIED INDORSER
}

\author{
WILLIAMI E. BRITTON†
}

\section{Warranty With Respect to the Value of the Instrument ${ }^{1}$}

THERE is no general warranty that an instrument transferred by delivery or qualified indorsement will be paid, or that prior parties are solvent. Such a transferor, however, does warrant that he has no knowledge that the instrument is valueless.

"It is extremely clear," said Lord Kenyon, in an early case, "that if the holder of a bill of exchange sent it to market without indorsing his name upon it, neither morality or the laws of this country will compel him to refund the money for which he has sold it if he did not know at the time that it was not a good bill. ... . If the defendants had known the bill to be bad there is no doubt but that they would have been obliged to refund the money."2

The question, as to what facts, when known by the transferor, will cast upon him this additional liability, is not definitely answered. It is said that knowledge of the maker's insolvency is sufficient. ${ }^{3}$ Insolvency as here used apparently means suspension of payments. It has even been held that knowledge by the transferor of the existence of another dishonored check of the same party whose instrument was transferred by him was evidence sufficient to prove known

$\doteqdot$ Professor of Law, University of Illinois.

1. This is a continuation of the article which appeared in (1930) 40 YALE I. J. 215.

2. Fenn v. Harrison, 3 T. R. 757 (K. B. 1790). Accord: Popley v. Ashley, 6 ITod. 147 (K. B. 1705); Read v. Hutchinson, 3 Campb. 351 (N. P. 1812); Bicknall v. Waterman, 5 R. I. 43 (1857), where the court said: "the vendee takes the risk of past insolvency of the maker or other party to it, unless indeed in case of past insolvency the vendor is guilty of the fraud of passing it of with knowledge of that fact." Burgess v. Chapin, 5 R. I. 225 (1858); Fonda v. Garland, 7 La. Ann. 201 (1852); Winter v. Bullock, 6 Ga. 232 (1849); Gordon v. Irvine, 105 Ga. 144 (1898); Dayton v. Tillotson, 39 Iowa 404 (1874), where the court held the following instruction should have been given: "In all cases where the assignor, whether by delivery or indorsement without recourse of a negotiable instrument, knows it to be of no value.. the assignor may be compelled to repay or return the consideration thus received."

3. Winter v. Bullock, 6 Ga. 232 (1849); Hoopes v. Strasburger, 37 Ird. 390 (1872). 
insolvency.4 Somewhat in contrast to this case the same court, at a later time, held that knowledge that an acceptor was resorting to unusual methods for the borrowing of money was not such a fact as tended to show that the instrument transferred was valueless. ${ }^{5}$

Whatever the boundary limits of this common law rule may be, it is clear that it was sought to be codified in Section 65 (4) of the Negotiable Instruments Law, which provides that "Every person negotiating an instrument by delivery or by a qualified indorsement, warrants that he has no knowledge of any fact which would impair the validity of the instrument or render it valueless."

The warranty with respect to the value of the instrument is confined to cases where the transferor has knowledge tending to induce belief that it will not be paid. Where there is no such knowledge there is no liability. At this point arises a question somewhat analogous to that under discussion, i.e., as to the circumstances under which a transfer of a negotiable instrument of a third party by delivery alone or by indorsement without recourse will operate as a discharge of the obligation sought to be paid. When the primary obligor on such instrument fails to pay, because of insolvency or otherwise, may the creditor sue the debtor, transferor, on the original debt? A complete discussion of this question is not here attempted. There is much uncertainty and conflict in the cases. Several of the leading ones are collected in the notes following. Suffice it to say, there is a line of cases holding that a transfer of a negotiable instrument by delivery or qualified indorsement, in payment of a contemporaneous obligation of the transferor, operates as a discharge of such obligation, even though the instrument be subsequently dishonored by the primary obligor thereon. That is, the creditor could not thereafter sue the debtor on the underlying debt or in any way hold him liable because of the dishonor of the instrument. This result is, of course, quite in harmony with the rule that the transferor does not warrant that the instrument will be paid, or that the obligors thereon are solvent. In such a case if the creditor desires the continued liability of his debtor he must obtain his unqualified indorsement.

Where, however, the transfer was made in payment of an antecedent obligation of the transferor, and the instrument proved un-

4. Brown v. Montgomery, 20 N. Y, 287 (1859), where Story J. said: "ho nevertheless warrants that he has no knowledge of any facts which provo tho paper to be worthless. ..." Followed in Boston National Bank v. Armour, 53 Hun *629, 6 N. Y. Supp. 714 (Sup. Ct. 1889). Accord: Young v. Adams, 6 Mass. 182 (1810).

5. People's Bank of the City of New York v. Bogart, 81 N. Y. 101 (1880). 
collectible, the creditor has been allowed to recover from the debtor on the underlying debt. That is, such a transfer operates only as conditional payment. This aspect of the rule is somewhat like a warranty with respect to the value of the instrument but actually it is not so because the creditor's action is always on the underlying obligation. He does not sue the debtor on any independent implied warranty. Some of the cases most often cited on the distinction between the effects of transfers in payment of contemporaneous and precedent debts are collected in the note. ${ }^{\circ}$ The cases dealing with

6. Clerk v. Mundell, 12 Mod. 203 (K. B. 1699); Bank of England v. Newman, 1 Ld. Raym. 442 (K. B. 1700); Ward v. Evans, 2 Ld. Raym. 929 (K. B. 1704) ; Hartop v. Hoare, 3 Atk. 44 (Ch. 1743); Ex parte Roberts, 2 Cos Eq. Cas. 170 (Ch. 1789) ; Fenn v. Harrison, 3 T. R. 757 (K. B. 1790), 4 T. R. 177 (K. B. 1791) ; Puckford v. Maxwell, 4 East 448 (K. B. 1794); Fydell v. Clark, 1 Esp. 447 (N. P. 1796); Ex parte Shuttleworth, 3 Ves. 367 (Ch. 1797). In Ex parte Blackburne, 10 Ves. 205 (Ch. 1804), Lord Eldon recognized the distinction in the following language: "I take it to be now clearly settled, that if there is an antecedent debt and a bill is taken, without taking an indorsement, which bill turns out to be bad, the demand for the antecedent debt may be resorted to. It has been held, that if there is no antecedent debt and $A$ carries a bill to $B$ to be discounted and $B$ does not take A's name upon the bill, if it is dishonored, there is no demand; for there was no relation between the parties except that transaction; and the circumstance of not talking the name upon the bill is evidence of a purchase of the bill." In this case the dishonored bill had been received in payment of a precedent debt. The bill proved uncollectible and the creditor, transferee, was allowed to recover from the debtor on the original debt.

Emly v. Lye, 15 East 6 (K. B. 1812) ; Tobey v. Barber, 5 Johns. 68 (N. Y. 1809) (court relied on Clerk v. IIundell, supra); Johnson v. Weed, 9 Johns. 310 (N. Y. 1812) ; Whitbeck v. Van Ness, 11 Johns. 409 (N. Y. 1814); Gibson v. Tobey, 46 N. Y. 637 (1871); Roberts V. Fisher, 43 N. Y. 159 (1870); Wilmot Engineering Co. v. Blanchard, 208 App. Div. 218, 203 N. Y. Supp. 700 (3rd Dep't 1924); Partee v. Bedford, 51 Miss. 84 (1875) (relying on Clerl: v. Mundell, supra, Bank of England v. Newman, supra, and Whitbeck v. Van Ness, supra); Glen v. Smith, 2 G. \& J. 493, 509 (Mrd. 1830) (also relying on the early English cases and Tobey $\nabla$. Barber, 5 Johns. 68 (N. Y. 1809) ); Caldwell v. Hall, 49 Ark. 508, 1 S. W. 62 (1887), where the court said: "It is an established rule of law that the acceptance by a creditor of the note of a third person for a preëxisting debt will not discharge the original cause of action unless by agreement of the parties it is taken in payment of the prior debt." Accord: Brown v. Olmsted, 50 Cal. 162 (1875); Hunter v. MIoul, 98 Pa. St. 13 (1881); Shepherd v. Busch, 154 Pa. St. 149 (1893); League v. Waring, 85 Pa. St. 244 (1877); Sullivan v. Saunders, 66 W. Va. 350 (1909); Young v. Hibbs, 5 Neb. 433 (1877); Wilhelm v. Schmidt, 84 Ml. 183 (1876); Wainwright $\vee$. Webster, 11 Vt. 576 (1839). "Well established that where a note of a third person is received in payment of a precedent debt the risl of solvency of the maker is upon the party from whom the bill is received." Harley $\nabla$. Thornton (1833), reported in a note to Brumby v. Dugan, 2 Hill 508 (S. C. 1834). 
the effects of transfers of bank notes in payment of present or antecedent indebtedness of the transferor treat the problem somewhat differently and there is conflict among them. ${ }^{7}$ The whole matter is referred to here only for the purpose of calling attention to the fact that there are cases where the transferor assumes the risk of non-payment of instruments transferred by him, although this liability is not enforced by an action for breach of warranty or by rescission. This being so, there is no reason to assume that the Negotiable Instruments Law would in any way change whatever rule may be in force. The question is one as to what constitutes payment and this term is not so defined in the Act as to make mandatory the adoption of any particular conception of it.

\section{To Whom Warranties Run}

AT common law the warranties of a transferor by delivery and of a qualified indorser ran only to their immediate transferees who paid value. ${ }^{8}$ In one state, at least, remote assignees are allowed to

Cf. Wiseman v. Lyman, 7 Mass. 286 (1811); Ely v. James, 123 Mass. 36 (1877); Day v. Kinney, 131 Mass. 37 (1881); Hecht v. Batcheller, 147 Mass. 335 (1888). And compare: Bartsch v. Atwater, 1 Conn. 408 (1815); Dillo v. White, 132 Iowa 327, 109 N. W. 909 (1906); Garretsie v. Van Ness, 2 N. J. L. 17 (1806); Mackie's Ex. v. Davies, 2 Wash. 219 (Va. 1796); Saunders v. Marshall, 4 H. \& M. 455 (Va. 1809).

7. Transfer of a bank note of a failed bank discharged the dobt, whother contemporaneous or precedent, subject, however, to the condition that if the creditor presented the note to the bank within a reasonable time and failod to obtain the money, and notified the debtor, the transferor would bo hold liable on the original debt in both cases. Tassel v. Lewis, 1 Ld. Raym. 743 (I. B. 1700); Moore v. Warren, 1 Strange 415 (K. B. 1721); Manwaring v. Harrison, 1 Strange 508 (K. B. 1722) ; Stedman v. Gooch, 1 Esp. 3 (N. P. 1793); Camidgo v. Allenby, 6 B. \& C. 372 (K. B. 1827); Turner v. Stones, 1 D. \& L. 122 (Eng. Bail Ct. Rep. 1843) ; Timmins v. Gibbins, 18 Q. B. 722, (1852); Guardians of the Poor of Litchfield Union v. Green, 26 Law Jour. Rep. Ex. 140 (1857).

Compare Massachusetts rule: Young v. Adams, 6 Mass. 181 (1810), in which a greater risk falls on the transferee of the notes of a failed bank than undor the English rule. And along the same line compare Bayard v. Shunk, 1 W. \& S. 92 (Pa. 1841); Scruggs v. Gass, 8 Yerg. 175 (Tenn. 1835); Ware v. James A. Street Co., 39 Tenn. 609 (1859); Edmunds v. Digges, 1 Grat. 360 (Va. 1845); and Lowrey v. Murrell, 2 Porter 280 (Ala. 1835).

New York rule: Lightbody v. The Ontario Bank, 11 Wend. 9 (N. Y. 1833), 13 Wend. 101 (N. Y. 1834), draws no distinction between the offect of transfors of bank notes of a failed bank and the notes of third parties generally. Accord: Gilman v. Peck, 11 Vt. 516 (1839); Wainwright v. Webstor, 11 Vt. 576 (1839); Townsend v. Bank of Racine, 7 Wis. 185 (1859). And compare the following cases: Magee v. Carmack, 13 Ill. 289 (1851); Bank v. Morse, 22 Mo. 88 (1842) ; Corbit v. Bank of Smyrna, 2 Harr. 235 (Del. 1837).

8. Watson v. Chesire, 18 Iowa 202 (1865); Brown v. Summers, 01 Ind. 151 (1883); Mardis v. Tyler, $49 \mathrm{Ky} .376$ (1850); Elliot v. Threlkeld, 65 Ky. 341 (1855). 
sue by statute. ${ }^{9}$ And it has been suggested that a remote assignor, under special circumstances, may be reached in equity. ${ }^{10}$ In any event, the cause of action for breach of warranty could be expressly assigned. ${ }^{\mathrm{II}}$ The mere transfer of the instrument did not, of itself, operate as an assignment of the cause of action.12

Under the Negotiable Instruments Law ${ }^{13}$ the common law rule which restricts the right to sue for breach of warranty to immediate transferees is continued as regards transfers by delivery only. The Act provides: "But when the negotiation is by delivery only, the warranty extends in favor of no holder other than the immediate transferee." This language does not forbid the express assignment of such causes of action and this presumably may still be done under the Act. The implication of this section is that the warranties of the qualified indorser will run to remote holders. This point is not as clear as it should be but this conclusion seems the more reasonable

9. Broaddus Institute v. Siers, 68 W. Va. 125, 69 S. E. 468 (1910), the court saying: "This action could not have been maintained against defendant at common law because he was a remote assignor with whom plaintiff had no contract. (Citing Watson v. Chesire, supra note 8). But the West Virginia statute provides that an assignee may sue a remote assignor on his implied warranty."

10. An assignee of a non-negotiable instrument cannot sue a remote assignor "because there is no privity of contract between them. The recourse of an assignee against remote assignors can only be reached by a proceeding in the nature of a bill in equity setting forth the equitable circumstances which render such assignors liable to the last assignee." Weaver v. Beard, 21 Mro. 155 (1855).

11. Watson v. Chesire, 18 Iowa 202 (1865), where the court said: "It may be that Griffith (the indorsee without recourse from the payee) might specially assign his cause of action against Chesire (the payee and indorser without recourse) to the plaintiff (indorsee without recourse from Griffith) but the mere indorsement of the note without recourse would not have that effect."

And it was so held in Smith v. MreNair, $19 \mathrm{Kan} .330$ (1877), where $A$, the defendant, sold a forged school district bond to $B$. $B$ sold to $C$. The forgery was discovered. $B$ "assigned in writing his cause of action against $A$, the consideration for the assignment was the liability of $B$ to $C . " C$ recovered from $A$. The court said: "The implied warrantyl of genuineness by Smith \& Son, (defendant A.) was broken the instant of delivery and they at once became liable to their vendees for the amount they received. Defendants were in no wise affected by such second sale and could not plead such sale in bar of the rights of $B$ against them nor against $B$ 's assignee, $C$, who stands in the shoes of $B$ in this case."

12. Watson v. Chesire, supra note 11.

In harmony with the idea that the transfer of the instrument does not of itself operate as an assignment of a cause of action against a prior assignor, see Bankhead v. Owen, 60 Ala. 457 (1877), where it was held that a grantor's lien, while it passes by unqualified indorsement of the grantor of the notes representing the purchase price, does not pass by a transfer by delivery or indorsement without recourse.

13. $\$ 65$ (4). 
because the framers of the Act expressly mentioned qualified indorsers and transferors by delivery in the first part of Section 65 and refrained from incorporating any reference to qualified indorsers in the sentence above quoted. Moreover, a supporting inference is derived from Section 66, which provides that the warranties of unqualified indorsers run to remote holders. The draftsmen may have thought there was more reason to permit the warranties of former owners whose names appeared on the instrument, either as qualified or unqualified indorsers, to run to remote holders than there was to allow such actions against those former owners whoso names did not appear on the instrument.

Do the warranties of the qualified indorser run to all remote holders or only to remote holders in due course? It has been suggested $^{14}$ that because Section 66 provides that the warranties of the unqualified indorser shall run only to subsequent holders in due course, that this same restriction should be read into Section 65 . This possibility is conceivable but not desirable or necessary. It is believed that the section imposes liability on the qualified indorser to all remote holders whether holders in due course as regards him or any other obligor, or not. Of course, if a particular indorsee who derives title through an indorsement without recourse has knowledge of the facts which constitute the breach of warranty, he can be denied the right to recover for this reason, as is true generally with respect to actions for breach of implied warranty. There is no reason to assume that this line of common law decisions is not still available under Section 196 in the interpretation of Section 65.

Would the warranties of a special indorsee who transferred without indorsement run only to his immediate transferee? Such a person is one kind of transferor by delivery and on this view his liability would run no further. If the suggestion that the reason for making the distinction between transferors by delivery and qualified indorsers was that because the former's name did not appear on the instrument and the latter's name did appear, has merit, it would seem that the liability of a special indorsee who transferred without indorsement, would not run beyond his immediate transferee. The Section does, however, present a technical difficulty to this construction. The Section provides: "But when the negotiation is by delivery only, the warranty extends in favor of no holder" etc. A transfer by a special indorsee who does not indorse is not a negotintion under Section 30, nor is his transferee a technical holder under Section 191. Therefore, it could be urged that the case under dis-

14. By two of the judges in Moody v. Morris-Roberts Co., 38 Idaho 414, 226 Pac. 278 (1923). 
cussion is not controlled by Section 65. It is believed that this view should not for this reason prevail. The term "negotiation" should not always be confined to the straight jacket definition of Section 30 , under which a transfer to constitute a negotiation must be to a holder, as the latter term is defined in Section 191. It has been expanded in other connections and may very well be so here so as to include the transfer of a special indorsee who does not indorse. Moreover, the term "holder" may be given a meaning other than that of a "payee or indorsee .. . or the bearer of a bill or note payable to bearer" because this definition by Section 191, is not mandatory if the "context otherwise requires." However, there is another approach to this problem of construction. If one begins with the idea that it is desirable to interpret ambiguous statutory language in the Act in such a way as to increase the value of the instrument, then the terms "negotiation" and "holder" as used in the quoted language from Section 65, could be seized upon as a means of taking the case under discussion out of the express language and allowing it to be controlled by the negative implication thereof, i.e., that the liability of such a transferor would run to all remote transferees.

\section{Statute of Limitations}

As is true with respect to implied warranties of quality generally ${ }^{15}$ the breach, if any, occurs at the time of sale, hence the statute of limitations begins to run at the time of transfer. ${ }^{10}$ The point has been made that while the cause of action for breach of warranty which involves a total failure of consideration, begins to run from the time of transfer, where the failure was partial "the cause of action is not complete until the plaintiff has procured a judicial establishment of the failure of consideration and the extent thereof."17 And, it has been held that the statute of limitations does not begin to run until the plaintiff acquired knowledge of the breach or by the exercise of reasonable diligence could have done so. ${ }^{18}$ There

15. WHLISTON ON SAries (2d ed. 1924) § 212 (a).

16. McNeill $\nabla$. Knott, $11 \mathrm{Ga} .142$ (1852), where the court held: "If the note was paid by one of the makers, to the original holder, at the time it was indorsed, there can be no doubt, that a right of action accrued immediately in favor of plaintiff, upon the indorsement.". Flynn v. Allen, 57 Pa. St. 482 (1868); Blethen v. Lovering, $58 \mathrm{MIe} .437$ (1870), the court holding that "The liability of the defendant (indorser without recourse) accruing then at the time of his indorsement, the statute of limitations constitutes a bar." Willis v. French, 84 Me. 593 (1892).

17. Trustees of Broaddus Institute v. Siers, 68 W. Va. 125 (1910).

18. Ripley v. Withee, 27 Tex. 14 (1863); Persons v. Jones, 12 Ga. 371 (1853), where the court held: "The cause of action (deceit) of a transferee against his 
appears to be nothing in the Negotiable Instruments Law which would nullify or change the existing rule on limitations in any jurisdiction.

\section{Remedies}

AN indorsee or transferee may rescind the contract under which he acquired the instrument for fraud, or mistake or for breach of warranty, according as the facts establish such rights and the consequent causes of action for recovery of the consideration parted with. He may also maintain an independent action for deceit, ${ }^{10}$ if the facts support it, or for breach of warranty. If the purchaser of the instrument rescinds for breach of warranty the parties are put back in the position they occupied before the transfer was made. If he brings an independent action for breach of warranty the contract is enforced. The distinction between rescission and independent action was well put by the Supreme Court of West Virginia in the following language:

"The assignee [from an indorser without recourse] has a right of election between rescission on the one hand, involving surrender of the paper and action for the whole consideration paid, and affirmance on the other, with a right of action for breach of warranty. In the first case, he would look to the assignor only. In the other, he would hold both parties, the acceptor, maker or obligor for the valid part of the debt and the assignor for the balance."20

Other cases bearing on this distinction are collected in the note..$^{21}$ Some courts are not inclined to adopt the distinction between

transferor of a note void for usury between the maker and payee, accrued instantly upon transfer of the usurious paper," but the statute of limitations began to run from the date the plaintiff acquired knowledge of the causo of action. In Camp Manufacturing Co. v. Durham Fertilizer Co., 150 N. C. 417 (1909), the court did not take a definite position on the point but held the cause of action for breach of warranty that a judgment was valid arisos "in any event at the time the assignee learned of the breach." Cf. P. H. Sheohy Co. v. Bastern Mfg. Co., 44 App. D. C. 107 (1915).

19. Jamison v. Copher, 35 Mo. 483 (1865) (indorsee from an unqunlified indorser allowed to recover from his indorser in an action of decoit); Laruo จ. Barbee, $184 \mathrm{Ky} .354,212$ S. W. 142 (1919) (indorser without recourse held liable in his indorsee's action against him in deceit); Wallace \& Co. v. First Nat. Bank of Superior, 102 Neb. 358, 167 N. W. 416 (1918) (transferee of a note recovered from his transferor in deceit). Accord: Bridge v. Batchaldor, 9 Allen 394 (Mass. 1864).

20. Trustees of Broaddus Institute v. Siers, 68 W. Va. 125 (1910).

21. Coolidge v. Brigham, 42 Mass. 547 (1840), where the court snid: "The plaintiff was at liberty either to restore the note to the defendant or to retain 
rescission and its consequent action to recover what was parted with and an independent action for breach of warranty.? Return of the instrument is a condition precedent to the vendee's right of rescission and to his right of recovery of the consideration paid to his vendor. ${ }^{23}$ But this condition precedent may be waived by the vendor. ${ }^{24}$ But where the instrument is valueless for all purposes its restoration to the vendor is not a condition precedent to the vendee's right to recover the consideration paid. ${ }^{25}$ But the mere fact that the instrument in question bears the forged signature of the obligor and has no genuine indorsements thereon will not of itself destroy the condition. ${ }^{20}$

it and resort to his action on the varranty." And, again, the court in Delaware Bank v. Jarvis, 20 N. Y. 226 (1859), said: "On the part of the defendant (transferor) it has been insisted that the plaintiffs might have returned the note as worthless immediately after they received it, and at once commenced their action to recover back the money which they had advanced upon it. This is clearly so,... if he can and will restore the other to his previous situation. But they . . . were not bound to do so. The present action proceeds on an affirmance instead of a disaffirmance of the transaction between them and the defendant."

Webb v. Odell, 49 N. Y. 583 (1872) (rescission). And in Gabay v. Deane, 66 App. Div. 507, 73 N. Y. Supp. 381 (1st Dep't 1901), the court allowed a transferee to recover from his transferor on the latter's warranty that prior signatures were valid, eren though some of them were admittedly valid. "The fact that the note was not void as to Robinson did not preclude plaintiff from recovering the damages he sustained because of the fact that the note was void as to Riley." Summers v. Richie, 3 Yeates 531 (Pa. 1803), where the court said: "The plaintiff might retain the note and recover for breach of warranty or return the note and recover in the present form of action-[money had and received]."

22. It would seem to be more accurate to say that the right of recovery is for the purchase money, because of the failure of the consideration upon which it was paid, than to say that it is for the breach of an implied warranty that the article is that which was professed to be sold. Lunt v. Wrenn, 113 III. 168 (1885).

23. Coolidge v. Brigham, 1 Metc. 547 (Mass. 1840), 5 Mretc. 68 (1842); Delaware Bank ₹. Jarvis, 20 N. Y. 226 (1859); Baldwin v. Van Deusen, 37 N. Y. 487 (1868); Webb v. Odell, 49 N. Y. 583 (1872); Summers v. Richie, supra note 21.

24. Roth v. Grissy, $30 \mathrm{~Pa}$. St. 145 (1858).

25. "There was no necessity to return the scrip (for government land, certificates having been declared void) because it could be of no possible value to the owner." Lunt v. Wrenn, 113 IIl. 168 (1885). Similarly in Smith v. IICNair, 19 Kan. 330 (1877), recovery by a transferee against the transferor of a bond bearing the forged signature of the obligor was allowed without returning the bond, the court saying: "The bonds were forged and entirely worthless to all parties. In such case the return would be a useless ceremony which the law never requires."

26. "The reason why it is held, where payments have been made in counterfeit bills, the bills must be returned within a reasonable time to authorize the 
The burden is on the plaintiff to prove the breach of warranty by defendant. ${ }^{27}$ If the vendor has notice of the action by his vendee against a prior party he is concluded by the judgment in such action. ${ }^{28}$ It was at one time held in Kentucky ${ }^{20}$ that the liability of the vendor was conditioned upon the vendee's having first sued the prior party within a reasonable time after the sale. Not until judgment went against such vendee could the latter sue his vendor. But this decision requiring the judicial determination of the non-liability of a prior party as a condition precedent to, the liability of the vendor has been overruled. ${ }^{30}$ Some courts have held that the judgment in favor of the prior party will not be conclusive against the vendor unless, in addition to the receipt of notice by the vendee of his proposed action against such prior party, the vendee couples with the notice to the vendor a request that the vendor take charge of the litigation and that on his default the vendee will look to the vendor for indemnity. ${ }^{31}$ This view has been criticised. ${ }^{32}$

payee to recover from the payer, is to enable the payer to trace out and finll back upon the person from whom he received them." Lunt v. Wrenn, 113 Ill. 168 (1885).

27. Moore v. Worthington, $63 \mathrm{Ky} .307$ (1865), holding that where there is no proof that the instrument sold was not obligatory on the maker the transferee cannot recover from the transferor. Accord: Hunt v. Sandors, 288 Mo. 337,232 S. W. 456 (1921) (under N. I. L.).

28. Where the holder of a note fails to recover from the maker because of a forged indorsement on the instrument, and notice of this litigation was given to prior indorsers, the judgment is conclusive in an action by such holder against the prior indorser. First National Bank of Mount Vernon v. The First National Bank of Lincoln, 68 Ohio St. 43 (1903). Accord: Drennan v. Bunn, 124 IIl. 175 (1888).

29. Transferee sued the obligor of a note and on the latter's plea of non est factum, abandoned the action and sued his transferor. Held that this is insufficient proof of the maker's defense. Wynn v. Poynter, 3 Bush 54 (Ky. 1867), where the court said: "We repeat that to recover on the implied guaranty of genuineness, as well as to recover on the implied guaranty of solvency . . . an action on the bond must have been prosecuted with the snme legal diligence on each guaranty and surely in each case the genuineness or solvency must be judicially determined." This rule seems inconsistent with the earlier casos of Roberts v. Atwood, 8 B. Mon. 209, (Ky. 1847), and Emmerson v. Claywell, 14 B. Mon. 15 (Ky. 1853).

30. This rule was reluctantly followed in MaCormack v. Ware, $13 \mathrm{Ky} . \mathbf{L}$. 678 (1891), but expressly overruled in Ware v. McCormack, $96 \mathrm{Ky} .139$ (1804), where the court said: "The doctrine of Wynn v. Poynter, is overruled. . . . This [rule] we hold not to be the law. ... the vendee may sue [the vendor] at once to recover damages." Accord: Terry v. Bissell, 26 Conn. 23 (1857); Whitney v. The National Bank of Potsdam, 45 N. Y. 303 (1871).

31. Paul v. Whitman, 3 W. \& S. 410 (Pa. 1842); Sowers v. Schmidt, 24 Wis. 417 (1869).

32. Drennan v. Bunn, 124 Ill. 175 (1888). 
But it has been held that where a vendee sues the obligor in the courts of one state and is defeated because of a defense good as against him, such judgment is not conclusive as to the existence of the defense in an action by such vendee against his indorser without recourse. ${ }^{33}$ Mere lapse of time before the defense of the prior party is discovered by the vendee will not bar his remedy against his vendor, though after discovery of such defense, notice thereof must be given within a reasonable time to his vendor. ${ }^{34}$

\section{Measure of Damages}

AN indorsee of a negotiable instrument who acquires title from an unqualified indorser at a discount, in the event of dishonor, may recover from the indorser the full face value of the instrument. ${ }^{36}$ The same rule should obtain where the transferee by delivery or indorsee from a qualified indorser sues for breach of warranty, yet most of the cases seem to treat such actions, on the question of

33. Kail v. Bell, 88 Kan. 666 (1913).

34. Frank v. Lanier, 91 N. Y. 112 (1883); Rick v. Kelly, 30 Pa. St. 527 (1858), where the court said: "The judgment of the court is that notice of the forgery within a reasonable time after its discovery and an offer to return the note are necessary to the maintenance of an action for the recovery of the money, unless the note be shown to possess no value." In Thomas v. Todd, 6 Hill 340 (N. Y. 1844) something less than two months was held too long. In Raymond v. Bear, 13 S. \& R. 318 ( $\mathrm{Pa} .1825$ ), six months was held gross negligence. In Gloucester Bank v. The Salem Bank, 17 Miass. 33 (1820), a failure of fifteen days was held to defeat the action.

35. Roark v. Turner, 29 Ga. 455 (1859) (indorsee who paid defendant indorser $\$ 1750$ for a note for $\$ 1950$, was allowed to recover the face of the note). The dissenting judge argued that, under the rule adopted, "the indorsement amounted to a promise by him to pay $\$ 1950$ in consideration of receiving $\$ 1750$. Now I say that for this promise there was a want of consideration to the extent of $\$ 200 . "$ To which the majority replied: "If the consideration on both sides was money this reasoning might da . . . but the fallacy consists in assuming that in such other cases equality of values is attainable. . . . A promise is a species of property and has no more a fixed money value than a horse. For the reason that the law cannot weigh the value of the promise it leaves the parties to adjust it by their contract." Accord: Felton v. Smith, 88 Ind. 149 (1882); National Bank of Michigan $\vee$. Green, 33 Iowa 140 (1871) (refers to the conflict and adopts the above rule); Durant $\nabla$. Banta, 27 N. J. L. 624 (1858), where the court said: "As to the doctrine that the indorsee of a note who buys it at less than its face can only recover from the indorser the amount paid him with interest, in case the maker does not pay it, seems to be without any foundation in law." Van Vleet v. Sledge, 45 Fed. 743 (C. C. W. D. Tenn. 1890), after referring to the "diversity of ruling on the point" said that "the sounder principle is found in the rule which makes the indorser liable for the face of the note (for) his legal undertaking is that he will pay the note if the maker fails to do so at maturity on proper demand and notice." 
measure of damage, as though they were based on a rescission of the contract and limit recovery to the amount paid. ${ }^{30}$ The contrary rule which permits the purchaser to recover from the seller the full face value of the instrument, where it was obtained at a discount, seems preferable. ${ }^{37}$ Under both theories the purchaser is allowed to recover interest and costs incurred by him in suing the primary obligor. $^{38}$ The vendee recovers, not only the costs of his unsuccessful actions against antecedent parties but also the costs of successful actions brought against him by his vendee. ${ }^{30}$ If he has received

36. Cook v. Cockrill, 1 Stew. 475 (Ala. 1828), "where the consideration passing between the indorsee and indorser is not equal to the amount of tho note the indorsee, in an action against the indorser can only recover the considerntion which he has already paid." Accord: Coye v. Palmer, 16 Cal. 159 (1860); Ware v. McCormack, 96 Ky. 139 (1894).

Parlange v. Faures, 14 La. Ann. 448 (1859) ( $\$ 1200$ note sold for $\$ 1100$. Hold: judgment against the transferor should have been for $\$ 1100)$; Sere v. Fauros, 15 La. Ann. 189 (1860); Coolidge v. Brigham, 46 Mass. 68 (1842); Fronch v. Grindle, 15 I Me. 163 (1838); Klunk v. O’Fallon, 1 Mo. 264 (1824); McAdam v. Grand Forks Merc. Co., 24 N. D. 645, 140 N. W. 725 (1913); Aldrich v. Jackson, 5 R. I. 218 (1858) (transferee recovered \$781, the amount paid for an $\$ 800$ note) ; Hall v. Latimer, 81 S. C. 90 (1908) (indorsee of a note for $\$ 134$ recovered from his indorser without recourse $\$ 130$, the amount paid for the note); Daskam v. Ullman, 74 Wis. 474,43 N. W. 321 (1889).

37. Bennett v. Buchan, 61 N. Y. 222 (1874), where a judgment for $\$ 1,038.46$ against four partners was sold to plaintiff at a discount of $90 \%$. Prior thereto. the sole solvent judgment debtor had been released by the judgment creditors. In an action by the purchaser of the judgment against the sellor, the court held that it was error to enter judgment for the plaintiff for the purchaso price alone. "She [the vendee] was entitled to recover the difference between the value of the judgment as it was and its value if Gillet had not been released. The same rule must be applied which is applied in the case of breach of warranties in the sale of chattels."

38. Kingsley v. Fitts \& Avery, 55 Vt. 293 (1883), where an account for $\$ 121.61$ was sold for $\$ 100.00$, plaintiff recovered the $\$ 100.00$ plus interest and costs of an unsuccessful suit against the obligor, making a total of $\$ 107.10$, for which judgment was entered. "The assignee is entitled not only to recover the amount paid for the note, with its interest, but all the costs and expenses. incurred in the prosecution of the action to enforce its collection." Hurst v. Chambers, $75 \mathrm{Ky} .155$ (1876). Accord: Delaware Bank v. Jarvis, 20 N. Y. 226 (1859). Lawton $v$. Howe, 14 Wis. 241 (1861). The following cases support this rule, either directly or by implication: Sneed v. Hughes, 14 Ga. 542 (1854); French v. Turner, 15 Ind. 59 (1860); Baldwin v. Threlkeld, 8 Ind. App. 312, 34 N. E. 851 (1893); Snyder v. Reno, 38 Iowa 329 (1874); Smith v. MeNair, 19 Kan. 330 (1877); Elliot v. Threlkeld, $55 \mathrm{Ky} .341$ (1855); Hall v. Latimer, 81 S. C. 90 (1908). But the vendor will not be liable for costs of suit incurred in an action brought by the vendee against the maker, when, prior to suit the vendor made known to his vendee his willingness to pay the amount. of the note to him. Copp v. M'Dugall, 9 Mass. 1 (1812).

39. Frank v. Lanier, 91 N. Y. 112 (1883). 
any pecuniary advantage from the instrument, such sum will be deducted. ${ }^{40}$

\section{Warranties of the Unqualified Indorser}

AN unqualified indorser on negotiable paper is under two forms of liability ${ }^{41}$ to subsequent holders for value. He is liable as a vendor and also on his special contract of indorsement. As a vendor his liability is of the same nature as that of the qualified indorser and the transferor by delivery. The latter party's liability was worked out at common law on a theory of implied warranty against defenses and equities of prior parties. This theory was continued in Section 65 of the Negotiable Instruments Law. The liability of the unqualified indorser as a rendor might likewise have been so developed but the idea of estoppel was used to accomplish substantially the same results. ${ }^{42}$

At common law, the cases which involved the liability of an unqualified indorser were few in number, probably for the reason that the liability of the unqualified indorser, on his special contract of indorsement, as distinguished from his liability as a vendor, was sufficient to protect the holder. Having entered into the special

40. Lawton v. Howe, 14 Wis. 241 (1861).

41. The double aspect of the liability of an unqualified indorser is illustrated by the decision that his release "as indorser" does not release him as a vendor. Bevan v. Fitzsimmons, 40 Ill. App. 108 (1890).

42. Critchlow จ. Parry, 2 Campb. 182 (N. P. 1809); Ex parte Clark, 3 Brown C. C. 238 (Ch. 1791) ; Thicknesse v. Bromilow, 2 C. \& J. 425 (Ex. 1832); IIacGregor v. Rhodes, 6 E. \& B. 266 (K. B. 1856), where Lord Campbell said: "The defendants (regular indorsers) having, when they handed the bill to the plaintiff, represented the title as a just one, cannot now deny that it is so."

Accord: Woodward v. Harbin, 1 Ala. 104 (1840), the court saying: "A party who has indorsed a note, cannot when sued upon his indorsement, be allowed to object that the name of the maker or previous indorser is not genuine . . . and though they be forgeries in fact, a subsequent indorser cannot set up such a defense;" Burrill v. Smith, 7 Pick. 291 (Mass. 1828), ("indorser not at liberty to deny the validity of the contract which he has assigned"); State Bank v. Fearing, 16 Pick. 533 (Miass. 1835) (indorser "admitted the legal ability and signature of every antecedent party"); Prescott Bank v. Caverly, 7 Gray 217 (Miss 1856); Dalrymple จ. Hillenbrand, 62 N. Y. 5 (1875) (indorser "cannot deny the fact" that the instrument was executed by the firm in whose name it was executed); Donohoe v. Meeker, 35 App. Div. 43, 54 N. Y. Supp. 286 (3rd Dep't 1898) (indorser "estopped from asserting invalidity"); Beal v. Alexander, 6 Tex. 531 (1851) (indorser "cannot be heard to question competency"); Crosby v. Wright, 70 Minn. 251 (1897) (unqualified indorser cannot deny that the maker of the note was not a corporation); Henderson $v$. Lemly. 79 N. G. 169 (1878) (indorser estopped to deny that maker's name was signed without authority). 
contract, there was rarely any occasion for resort to a different theory of liability, narrower in scope and somewhat overshadowed if not concealed by the special engagement. Nevertheless it is believed that at common law the liability of the unqualified indorser as a vendor was the same as that of the qualified indorser and transferor by delivery. The only difference was that the one used the idea of estoppel to produce the results, the other, the theory of warranty.

The difference between the two forms of liability is important. An action on the indorser's special contract of indorsement is conditioned on presentment, notice and protest; his liability for breach of warranty is not so conditioned. ${ }^{43}$ Again, the action on the special engagement cannot be brought until maturity of the instrument while the action for breach of warranty, occurring as it does at the time of transfer, may be brought at any time.44

The implied warranties of a qualified indorser, of a transferor by delivery and of an unqualified indorser should be identical, because the liability of each party arises from the fact, common to each, of a transfer for value. At common law this was true except as modified by Littauer $v$. Goldman. ${ }^{45}$ This exception was codified in Section 65 (4). One would expect it to be introduced into Section 66 , which fixes the warranties of the unqualified indorser. But for some reason, this policy was not adopted. The result is that the liability of an unqualified indorser as a warrantor is substantially different from that of the qualified indorser and transferor by delivery.

43. Cochran v. Atchison, 27 Kan. 728 (1882), where the court said: "It is well settled by the authorities, if it turns out that any of these latter ongagoments are not fulfilled (presentment and notice), the indorser may be sued for the recovery of the original consideration which has failed or be held liablo as a party without proof of demand and notice." Accord: Copp v. M'Dugall, 9 Mass. 1 (1812) ; Furgerson v. Staples, 82 Me. 159, (1889), where the court said: "If the note transferred by indorsement be a forgery or absolutely void for any other reason, the indorser may be sued for the original consideration paid him. . . without demand and notice." Turnbull v. Bowyer, 40 N. Y. 456 (1869).

44. Chandler v. Mason, 2 Vt. 193 (1829). In this case the indorsee failed to recover from an unqualified indorser because of no demand or notice. Court said that if the common counts were added plaintiff conld recover. "None of us entertain any doubt but that the plaintiff, upon a proper declaration, and clearly establishing that the note was without consideration and void, might recover of the defendant without showing a demand of the maker." . . . In such case "the indorsee may forthwith sue the indorser and recover if ho can show the note thus indorsed to be a mere nullity. . . He need not wait till the note becomes payable, nor demand payment, nor give notice back."

45. 72 N. Y. 506 (1878). 
The similarities and differences between the liability of an indorser without recourse and transferor by delivery, on the one hand, and that of the unqualified indorser on the other, are as follows. The liabilities imposed by Section 65 (1) (2) and (3), i.e., the warranties against real defenses and outstanding legal titles, are expressly incorporated in Section 66 (1). This sub-section provides: "Every indorser who indorses without qualifications warrants to all subsequent holders in due course the matters and things mentioned in subdivisions one, two and three of the next preceding section." At this point identity of liability between the two groups of vendors of negotiable paper ends, and differences begin. By Section 65 (4) the qualified indorser and transferor by delivery warrant "that he has no knowledge of any fact which would impair the validity of the instrument or render it valueless." In lieu of this warranty the unqualified indorser, under Section 66 (2) warrants "that the instrument is at the time of his indorsement valid and subsisting." Thus the qualified indorser and transferor by delivery warrant ignorance of invalidity and the unqualified indorser warrants against invalidity irrespective of his lmowledge or ignorance of the facts. This difference is considerable. As previously pointed out, the probabilities are that Section 65 (4) will be construed to impose a warranty against all personal defenses only when the defendant had knowledge of the facts constituting such defense. The unqualified indorser by Section 66 (2) warrants against all personal defences, for if he warrants that the instrument is "valid and subsisting" he must warrant that all prior parties are liable. If personal defenses are outstanding the instrument could not be regarded as "valid and subsisting", except on the theory that as regards personal defenses an instrument could be said to be subsisting in the hands of a holder in due course.

When the Negotiable Instruments Law is amended Section 65 (4) and Section 66 (2) should be made harmonious, preferably by repealing this aspect of Section 65 (4) and substituting for it the language of Section 66 (2).

A second difference between the warranties under Section 65 and Section 66 is that under Section 65 there is a warranty that the qualified indorser and the transferor by delivery "has no knowledge of any fact which would . . . render it [the instrument] valueless." Under Section 66 there is no similar warranty. Of course, the unqualified indorser will be liable in such case on his special engagement as an indorser but this liability is conditioned on presentment and notice while that on the warranty would not be, and his liability as an indorser would not arise until maturity of the instrument, while that on a warranty would exist from the time of transfer. 
A third possible difference between the liabilities under Section 65 and Section 66, involves the parties to whom liabilities run. Under Section 65, the warranties of one who negotiates by delivery "extends in favor of no holder other than the immediate transferee." As stated above, under this section the liability of the qualified indorser, by implication, runs to all subsequent holders whether holders in due course or not. In all probability, the warranty could not be enforced by one who at the time of transfer had knowledge of the facts which constituted the breach of warranty for in such case the warranty may be deemed negatived by extrinsic facts. In Section 66, however, the warranties of an unqualified indorser run "to all subsequent holders in due course". The negative implication is that such warranties do not run to holders not in due course. Why this difference between the two sections? It is believed there is none, if Section 66 is properly construed. The expression "holder in due course" as used in Section 66 means something quite different from what it does elsewhere in the Act. It is believed that all the framers of the Act meant to convey by saying that warranties ran only to holders in due course was that they would run only to purchasers for value who had no knowledge of the facts constituting the breach of warranty. That is, they expressly incorporated in Section 66, the common law rule that knowledge of such facts negatived the implied warranty. They did so in rather unusual language. But this is no more unusual than to have omitted the same common law qualification in Section 65. Unless the term "holder in due course" in Section 66 is given the special meaning above suggested, results in certain cases will be quite unjust. To illustrate: the plaintiff is an indorsee for value after maturity in good faith from a fraudulent payee. Not being a holder in due course he could not recover from the maker. Would it seriously be contended that he could not recover from the payee indorser on the latter's warranty that the instrument was "valid and subsisting"? Moreover, such construction brings Section 65 and Section 66 into harmony on the matter as to the parties to whom liabilities run, as they should be. 